\section{Influence of operation conditions on the carbon deposition of SOFC fuelled by gasified-syngas with tar included}

\author{
M. Liu ${ }^{1}$, M.G. Millan ${ }^{2}$, P.V.Aravind ${ }^{1}$, N. Brandon ${ }^{3}$ \\ 1. Process and energy department, Delft University of \\ Technology, Leeghwaterstraat 44, 2628 CA, Delft, The \\ Netherlands \\ 2. Chemical engineering, Imperial College London, SW7 \\ 2AZ, London, United Kingdom \\ 3. Earth science and engineering, Imperial College \\ London, SW7 2AZ, London, United Kingdom
}

The integration of Solid Oxide Fuel Cells (SOFC) and biomass gasifier is an attractive option for future clean renewable power generations [1]. However, the biosyngas from biomass gasifiers contains several contaminants such as tar, particulates etc. While tar is a contaminant for most of the power generation devices such as IC engines turbines etc, it may become fuel for the SOFCs operated under well designed conditions $[2,3]$ and hence the gas cleaning unit for tar removal may be built at a reduced cost. In real applications, the influence of tar from biomass gasification on the SOFC performance and durability has not been well established. One of the important problems tar might cause in SOFCs is carbon deposition. This paper presents the results from experimental investigations on the influence of operation conditions on the mitigation of carbon deposition arising from tar (toluene as model-tar) on SOFCs fuelled by gasified-syngas.

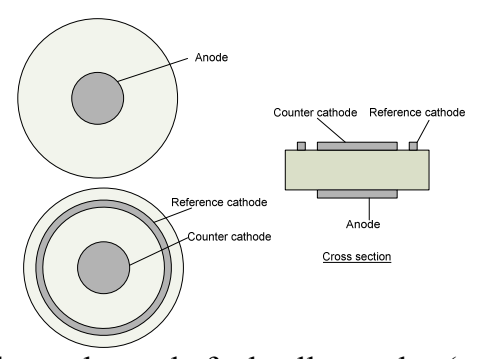

Figure 1. Three-electrode fuel cell samples (not in scale)

Experimentally measured syngas composition and tar concentration from an installed downdraft fix-bed gasifier were employed. Three-electrode SOFC with $\mathrm{Ni} / \mathrm{YSZ}$ anode samples as shown in figure 1 were prepared for evaluating the anode performance in terms of electrochemical impedance and polarization behavior (current density-potential cure). Thermodynamic calculations were also carried out to predict the carbon deposition arising from the model-tar under given conditions. Schematic view of the experimental set up is given in figure 2 and working conditions were tabulated as given in table 1 .

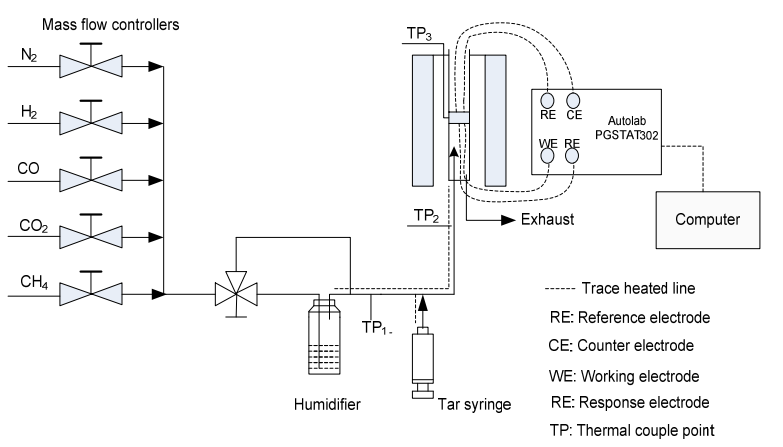

Figure 2. Schematic view of the experimental set up
The following results were obtained from the experiments. For the SOFC operated with tar-included syngas at a certain current load, increasing steam concentration within the syngas would mitigate carbon deposition as reflected by impedance change in figure 3. For the SOFC operated with tar-included syngas at a certain steam level, increasing fuel cell current load also reduces the risk of carbon deposition. These have a similar trend with that predicted by thermodynamic calculations. The paper will present the results from the experiments together with a detailed analysis.

Table 1 Working conditions used in measurements

\begin{tabular}{cc}
\hline Average dry syngas & $\mathrm{H}_{2} 16 \%, \mathrm{CO} 16 \%, \mathrm{CH}_{4}$ \\
composition & $1.5 \%, \mathrm{CO}_{2} 20 \% \mathrm{~N}_{2} 46.5 \%$ \\
\hline Tar concentration & $0-6 \mathrm{~g} / \mathrm{Nm}^{3}$ \\
Steam level & $0-10 \%$ \\
Current load & $0-150 \mathrm{~mA} / \mathrm{cm}^{2}$ \\
Temperature & $700-850{ }^{\circ} \mathrm{C}$ \\
\hline
\end{tabular}

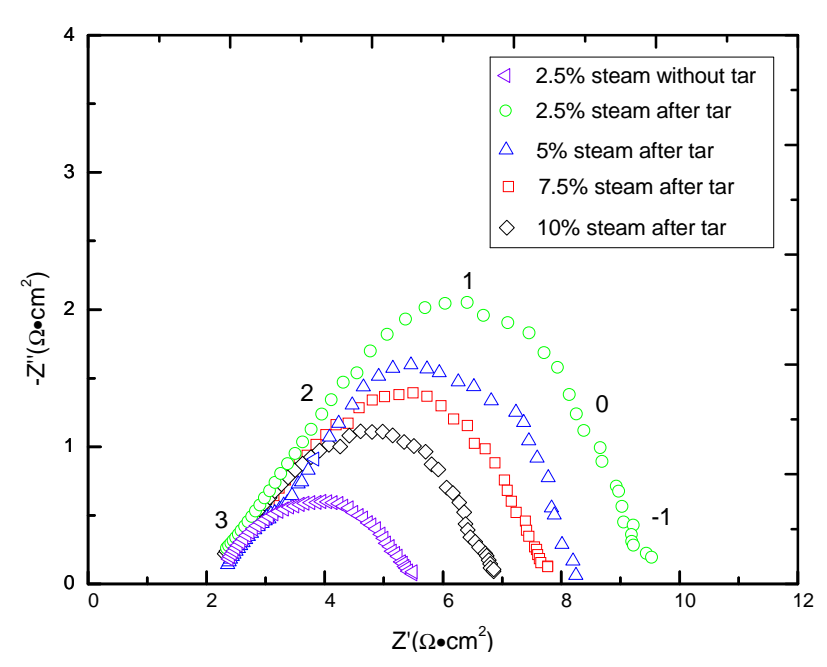

Figure 3. Impedance spectra of SOFCs with Ni/YSZ anodes at $150 \mathrm{~mA} / \mathrm{cm}^{2}$ fuelled by biosyngas exposed to $6 \mathrm{~g} / \mathrm{Nm}^{3}$ model-tar for $45 \mathrm{~min}$ in humidified steam.

\section{Reference}

[1] A.O. Omosun, A. Bauen , N.P. Brandon, C.S. Adjiman, D. Hart, Modelling system efficiencies and costs of two biomass-fuelled SOFC systems Journal of power sources, 131(2004), pp.96-106.

[2] P. V. Aravind, J. P. Ouweltjes, N. Woudstra and G. Rietveld, Impact of Biomass-Derived Contaminants on SOFCs with Ni/Gadolinia-Doped Ceria Anodes, Electrochemical and Solid-State Letters, 11(2008),pp.B24-B28 .

[3] Ph. Hofmann, K.D. Panopoulos, P.V. Aravind, M. Siedlecki, A. Schweiger, J. Karl, J.P. Ouweltjes, E. Kakaras, Operation of solid oxide fuel cell on biomass product gas with tar levels $>10 \mathrm{~g} \mathrm{Nm}^{-3}$, International journal of hydrogen energy, 34(2009), pp. 9203-9212. 